\section{Root Medium Carbon Dioxide and Oxygen Partial Pressures for Container-grown Chrysanthemums}

\author{
William R. Argo ${ }^{1}$ and John A. Biernbaum ${ }^{2}$ \\ Department of Horticulture, Michigan State University, East Lansing, \\ MI 48824-1325

\section{William C. Fonteno ${ }^{3}$ \\ Department of Horticultural Science, North Carolina State University, Raleigh, NC 27695-7609}

\begin{abstract}
Additional index words. aeration, Dendranthema $\times$ grandiflorum, drip irrigation, soilless media, subirrigation
\end{abstract}

\begin{abstract}
Medium $\mathrm{CO}_{2}$ and $\mathrm{O}_{2}$ partial pressures were measured at three locations [3.8 (top layer), 7.5 (middle layer), and 10.3 (bottom layer) $\mathrm{cm}$ below the rim] in 15-cm-tall pots containing flowering chrysanthemums [Dendranthema $\times$ grandiflorum (Ramat.) Kitamura] grown in one of three root media. Average ambient medium $\mathrm{CO}_{2}$ and $\mathrm{O}_{2}$ partial pressures were $63 \mathrm{~Pa}$ and $21 \mathrm{kPa}$, respectively, and were similar in the three sampled layers in root media with an average moisture content of $50 \%$ to $60 \%$ of container capacity. Within 10 minutes after a drip-irrigation application of well water containing a titratable alkalinity to $\mathrm{pH} 4.5$ of $320 \mathrm{mg} \mathrm{CaCO} /$ /liter, the partial pressure of medium $\mathrm{CO}_{2}$ increased to $\leq 1600$ $\mathrm{Pa}$ and medium $\mathrm{O}_{2}$ decreased to $20.5 \mathrm{kPa}$ in the top and middle layers of the pot. With subirrigation, medium $\mathrm{CO}_{2}$ partial pressures increased to $\leq 170 \mathrm{~Pa}$ and medium $\mathrm{O}_{2}$ remained at $21 \mathrm{kPa}$. When reverse-osmosis purified water (titratable alkalinity to $\mathrm{pH} 4.5$ of $<20 \mathrm{mg} \mathrm{CaCO}$ /liter) was used instead of well water, the large increase in medium $\mathrm{CO}_{2}$ did not occur, indicating that the bicarbonate alkalinity in the irrigation water was the source of $\mathrm{CO}_{2}$. The high medium $\mathrm{CO}_{2}$ partial pressure measured after irrigation was not persistent; within 180 minutes, it returned to levels averaging $45 \%$ higher $(100 \mathrm{~Pa})$ than that measured before the irrigation. Medium $\mathrm{O}_{2}$ also had returned to ambient levels 180 minutes after the irrigation.
\end{abstract}

Root medium aeration is important when plants are produced in containers (Bunt, 1988; DeBoodt and Verdonck, 1971; Fonteno, 1988; Milks et al., 1989). Hanan (1964) measured $\mathrm{O}_{2}$ partial pressures (PP) in cut-flower beds ranging from 8 to $60 \mathrm{~cm}$ deep and containing media with various percentages of leaf mold, loam, peat, perlite, sand, and silt. At the 5- to $7-\mathrm{cm}$ depth within the beds, $\mathrm{O}_{2}$ PP ranged from 9.8 to $21 \mathrm{kPa}$, with the highest measured in the beds containing a soilless root medium [ 1 peat : 1 perlite (v/v)]. Paul and Lee (1976) found that the $\mathrm{O}_{2}$ diffusion rate correlated well with the growth of chrysanthemums in 13 root media. Fifteen percent air-filled porosity at container capacity was suggested for optimum $\mathrm{O}_{2}$ diffusion rates and plant growth in 12 -

Received for publication 17 Apr. 1995. Accepted for publication 20 Dec. 1995. We acknowledge the Michigan Agricultural Expt. Station and the Gloeckner Foundation for supporting this research. We also acknowledge A.C. Cameron for the use of the $\mathrm{CO}_{2}-\mathrm{O}_{2}$ analyzer as well as advice with the project. The use of trade names in this publication does not imply endorsement of the products named or criticism of similar ones not mentioned. The cost of publishing this paper was defrayed in part by the payment of page charges. Under postal regulations, this paper therefore must be hereby marked advertisement solely to indicate this fact.

${ }^{1}$ Graduate Research Assistant.

${ }^{2}$ Associate Professor.

${ }^{3}$ Professor. cm-tall pots. In studies of gas exchange with soilless container root media, $\mathrm{CO}_{2} \mathrm{PP}$ have been largely ignored. For example, Hanan (1964) also measured $\mathrm{CO}_{2} \mathrm{PP}$ in several of the media in cut-flower beds but not in those containing the 1 peat : 1 perlite medium.

Medium $\mathrm{CO}_{2} \mathrm{PP}$ is important because of its effect on solution $\mathrm{pH}$ and nutrient solubility. Lindsay (1979) reported that for soils at equilibrium with $\mathrm{CaCO}_{3}$ (calcareous), the measured $\mathrm{pH}$ varied from 7.3 to 8.5 , depending on the $\mathrm{CO}_{2}$ PP. Soil $\mathrm{pH}$ values of 8.5 in calcareous soils can be obtained only when the $\mathrm{PP}$ of $\mathrm{CO}_{2}$ in the soil is similar to that measured in the ambient atmosphere ( 30 to $40 \mathrm{~Pa}$ ). Because of factors such as root respiration, microbial activity, and organic matter degradation, averare reported at $300 \mathrm{~Pa}$, or 10 times higher than that measured in the air (Lindsay, 1979).

In the production of container-grown plants, age $\mathrm{CO}_{2} \mathrm{PP}$ in the soil atmosphere commonly respiration is considered higher than that of plants grown in mineral soils because of faster plant growth rates (Paul and Lee, 1976) and higher microbial respiration because of the high organic-matter content of most soilless container media (Bunt, 1988). Muckle (1990) suggested that the accumulation of $\mathrm{CO}_{2}$ in container media, resulting from root respiration, can reduce plant growth. However, $\mathrm{CO}_{2}$ PP from plants grown in containers under normal production conditions are unknown. Our objectives were to determine the effects of drip irrigation and subirrigation on the medium $\mathrm{CO}_{2}$ and $\mathrm{O}_{2}$ PP in three root media containing fully developed chrysanthemum plants.

\section{Materials and Methods}

The three root media tested were 1) $100 \%$ Canadian sphagnum peat (Fisons professional black bale Canadian sphagnum moss peat; Sun Gro Horticulture, Bellevue, Wash.), 2) $50 \%$ sphagnum peat and $50 \%$ no. 2 vermiculite (Grace-Sierra, Marysville, Ohio), and 3) $100 \%$ no. 2 vermiculite. A wetting agent (Aquagro L; Aquatrols, Pennsaulken, N.J.) was incorporated at the recommended rate $\left(0.2\right.$ liter $\left.\cdot \mathrm{m}^{-3}\right)$. A superfine dolomitic limestone $\left(\mathrm{CaCO}_{3}\right.$ and $\left.\mathrm{MgCO}_{3}\right)$ was added to the medium before planting to increase the initial $\mathrm{pH}$ to 6.0. Because of the different amounts of peat added to media 1,2 , and 3 , the amount of limestone incorporated was 6,3 , or $0 \mathrm{~kg} \cdot \mathrm{m}^{-3}$, respectively. Medium physical properties were determined in a 15 -cm-tall $\times 15$-cm-wide pot (1.7 liter) using the method outlined by White and Mastalerz (1966) (see Table 1).

The two irrigation methods were drip irrigation or flood subirrigation. With drip irrigation, two emitters were placed on the center of the media surface and water was applied for 5 min. Sufficient water was applied for a $30 \%$ leaching fraction. With subirrigation, pots were placed on a flood-subirrigation bench that was filled to a depth of $3 \mathrm{~cm}$. The bench required 10 min to fill and $10 \mathrm{~min}$ to drain. The water used with both irrigation methods had a titratable alkalinity to $\mathrm{pH} 4.5$ of $320 \mathrm{mg} \mathrm{CaCO}_{3} /$ liter (Chau, 1984).

Our experiment was conducted at Michigan State Univ., East Lansing, in a wellventilated glass greenhouse, with constant air circulation and cement floors. Five rooted cuttings of 'Bright Golden Anne' chrysanthemum were planted into each of the root media using $15-\mathrm{cm}$-tall $\times 15$-cm-wide plastic pots (1.7 liter). Plants were grown using the two irrigation methods for 2 weeks under long-day

Table 1. Root-medium air space (AS), water space at container capacity (CC) in a 15 -cm-tall pot, bulk density (BD) (in kilogram per cubed meter), and ambient medium $\mathrm{CO}_{2}$ partial pressure at three layers within the same pot. Gas measurements are the mean of five pots. Least significant difference (5\%) calculated using pooled SE of the data presented for $\mathrm{CO}_{2}$ partial pressures $=10 \mathrm{~Pa}$.

\begin{tabular}{lcccccc}
\hline \hline & & & & \multicolumn{3}{c}{$\begin{array}{c}\text { Medium } \mathrm{CO}_{2} \text { partial } \\
\text { pressure (Pa) }\end{array}$} \\
\cline { 5 - 7 } Medium & AS & CC & BD & Top & Middle & Bottom \\
\hline 100\% peat & 21 & 65 & 102 & 59 & 70 & 71 \\
$50 \%$ peat and 50\% vermiculite & 20 & 66 & 100 & 62 & 66 & 68 \\
$100 \%$ vermiculite & 32 & 54 & 126 & 53 & 61 & 64 \\
\hline
\end{tabular}


conditions ( $>12 \mathrm{~h}$ light) and 9 weeks under short-day conditions ( $<12 \mathrm{~h}$ light).

At flowering, three holes were made in each of two pots from each treatment at 3.8, 7.5 , and $10.3 \mathrm{~cm}$ below the rim. Black vinyl tape with a bead of silicon caulk was placed over each hole to create a septum. Water was applied as a normal irrigation using one of the two methods described previously. The water content of the root medium before the irrigation was between $50 \%$ and $60 \%$ of container capacity. Gas samples were removed from the root medium before the irrigation and at 10 , $20,30,60,120$, and 180 min thereafter with drip irrigation, and at $30,60,120$, and $180 \mathrm{~min}$ after the irrigation with subirrigation using a 1 -ml disposable syringe with a 22 -gauge $(0.64$ $\mathrm{mm}$ ) needle that was $2 \mathrm{~cm}$ long. We considered the possibility of outside air moving down along the pot-medium interface and contaminating the sample but thought that this threat was minimal due, in part, to the high porosity of the media relative to the sample volume. The experiment was repeated on two consecutive days with separate groups of plants for replication.

Medium $\mathrm{CO}_{2}$ and $\mathrm{O}_{2}$ PPs were determined using a sequential $\mathrm{CO}_{2}$ (ADC 225-MK3 analytical infrared gas analyzer; Analytical Development Co., Hertfordshire, England) and $\mathrm{O}_{2}$ (Ametek S-3A/II with a calcia-zirconia electrochemical detection cell; Ametek Co., Thermox Instrument Division, Pittsburgh) analyzer. With both irrigation methods, the bottom layer initially was saturated, and no gas sample was taken after the irrigation for the duration of the experiment. Root medium $\mathrm{pH}$ was sampled 1 week after the $\mathrm{CO}_{2}$ analysis using the 1 medium : 2 water (v/v) method, with $\mathrm{pH}$ measured with an ion-specific electrode directly in the slurry.

In a second experiment, well water (titratable alkalinity to $\mathrm{pH} 4.5$ of $320 \mathrm{mg} \mathrm{CaCO}_{3} /$ liter) or reverse-osmosis (RO) purified water (titratable alkalinity to $\mathrm{pH} 4.5$ of $<20 \mathrm{mg}$ $\mathrm{CaCO}_{3}$ /liter) was applied to a second group of flowering chrysanthemums in pots containing medium 1 or 2 . The second group of plants was grown under the same conditions and at the same time as those from Expt. 1. A gas sample was removed from the top and middle layers of the pot 10 min after the water application, and the $\mathrm{CO}_{2} \mathrm{PP}$ was measured as previously described.

There were two independent factors (medium and irrigation method) and two factors with equal correlation between measurements [time of sampling (time) and location within the pot (layer)]. Data were analyzed with a univariate analysis of variance for repeated measurement experiments, as suggested by Ott (1988), using general linear model (GLM) procedures of SAS (SAS Inst., Cary, N.C.) for the analysis of variance with repeated measurements. The Greenhouse-Geisser adjusted F value (Greenhouse and Geisser, 1959) was used to determine statistical significance of interactions of independent factors with time. Contrasts between the independent factors' main effects within specific time periods were calculated by the SAS GLM procedure.

\section{Results and Discussion}

Pre-irrigation $\mathrm{CO}_{2} \mathrm{PP}$ in the root medium at $50 \%$ to $60 \%$ of container capacity averaged 58, 66, and $68 \mathrm{~Pa}$ for the top, middle, and bottom layer of the pot, respectively (Table 1). The slight increase in medium $\mathrm{CO}_{2} \mathrm{PP}$ probably reflects the differences in water-filled porosity of the three layers as predicted by Fonteno (1988) and Milks et al. (1989). This increase over the ambient $\mathrm{CO}_{2} \mathrm{PP}$ measured inside the greenhouse (46 $\mathrm{Pa}$ ) probably reflects root respiration, the root medium degradation within the pot, and the resistance within the root medium to gas diffusion. In comparison, medium $\mathrm{O}_{2} \mathrm{PP}$ was $21 \mathrm{kPa}$ at all three layers in all root media (data not shown), similar to that measured by Hanan (1964) at 5 to $7 \mathrm{~cm}$ below the surface of a $50 \%$ peat and $50 \%$ perlite medium.
With drip irrigation, applying water with an alkalinity of $320 \mathrm{mg} \mathrm{CaCO}_{4} /$ liter caused a marked increase in medium $\mathrm{CO}_{2}$ at two levels within the pot after $10 \mathrm{~min}$, resulting in PP from 250 to $1600 \mathrm{~Pa}$ (Fig. 1, Tables 2 and 3). In general, the greater the peat content of the root medium, the more pronounced the increase in medium $\mathrm{CO}_{2}$. A corresponding decrease of $0.5 \mathrm{kPa}$ in the average medium $\mathrm{O}_{2} \mathrm{PP}$ was found in the top and middle layer after the irrigation (data not shown).

With subirrigation, medium $\mathrm{CO}_{2}$ also increased in the top and middle layers of the pot after applying the high-bicarbonate water (Fig. 1 , Table 2), but the increase was $\leq 10 \%$ of that measured in the same medium given drip irrigation. The trends in $\mathrm{CO}_{2}$ evolution among root media and within the pot were consistent with the drip irrigation results, but the overall difference was less than that of drip-irrigated

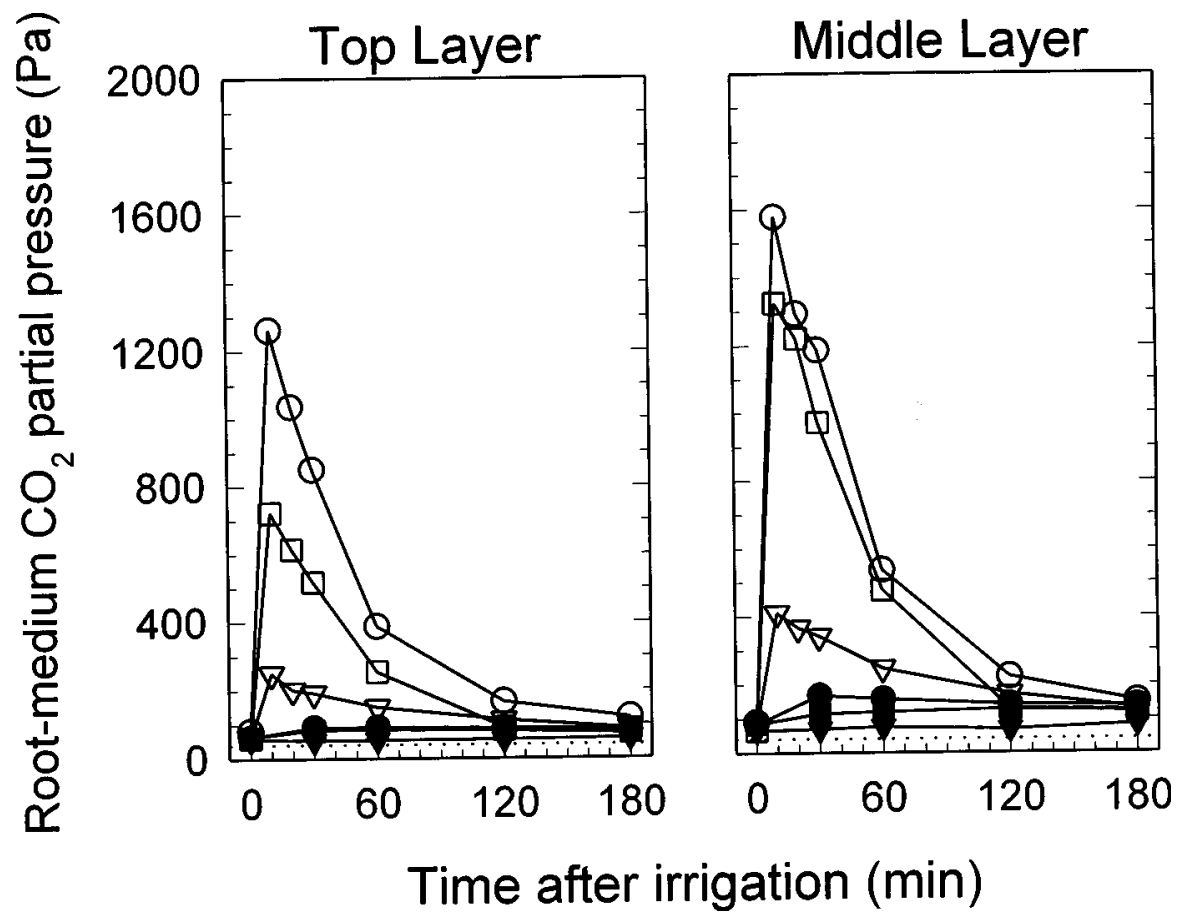

Fig. 1. Top- and middle-layer $\mathrm{CO}_{2}$ partial pressure of drip-irrigated (open symbols) and subirrigated (filled symbols) flowering chrysanthemums grown in 15 -cm-tall $\times 15$-cm-wide pots containing one of three root media. The media were $100 \%$ peat $(\bullet$ and $\bigcirc), 50 \%$ peat and $50 \%$ vermiculite $(\square$ and $\square$ ), and $100 \%$ vermiculite $(\boldsymbol{\nabla}$ and $\nabla)$. Dotted line indicates the ambient $\mathrm{CO}_{2}$ partial pressure inside the greenhouse. Each data point represents the mean of two pots.

Table 2. Summary of the univariate analysis of variance with repeated time measurements with levels of significance for root medium $\mathrm{CO}_{2}$ partial pressure at $0,30,60,120$, and $180 \mathrm{~min}$ at two depths within a 15 -cm-tall $\times 15$-cm-wide pot after applying irrigation water containing a titratable alkalinity to $\mathrm{pH} 4.5$ of $320 \mathrm{mg} \mathrm{CaCO}_{3}$ /liter with drip irrigation or subirrigation. No samples were taken from subirrigated pots at 10 and 20 min after the water application. Data are presented in Fig. 1.

\begin{tabular}{|c|c|c|c|c|c|c|}
\hline \multirow[b]{2}{*}{ Variable } & \multicolumn{2}{|c|}{$\begin{array}{c}\text { Independent } \\
\text { effects }\end{array}$} & \multicolumn{2}{|c|}{$\begin{array}{c}\text { Interactions of } \\
\text { independent effects } \\
\text { within time }\end{array}$} & \multicolumn{2}{|c|}{$\begin{array}{c}\text { Interactions of } \\
\text { independent effects } \\
\text { within layer }\end{array}$} \\
\hline & $\mathrm{df}$ & $\mathrm{MS}^{\mathrm{z}}$ & df & $\mathrm{MS}^{\mathrm{z}}$ & df & $\mathrm{MS}^{\mathrm{z}}$ \\
\hline Medium (M) & 2 & $172,815^{* * * *}$ & 8 & $53,714^{* * *}$ & 2 & $6,753^{\mathrm{Ns}}$ \\
\hline Irrigation method (IM) & 1 & $938,985^{* * *}$ & 4 & $337,024^{* * *}$ & 1 & $43,739^{* *}$ \\
\hline $\mathrm{M} \times \mathrm{IM}$ & 2 & $73,882^{*}$ & 8 & $45,021^{* * * *}$ & 2 & $2,649^{\mathrm{Ns}}$ \\
\hline Error & 17 & 13,665 & 68 & 3,414 & 53 & 4,312 \\
\hline Greenhouse-Geisser $\varepsilon$ & & & & 0.27 & & \\
\hline
\end{tabular}

${ }^{\mathrm{z}}$ Mean square from analysis of variance.

Ns, ${ }^{*},{ }^{* *},{ }^{* * *}$ Nonsignificant or significant at $P \geq 0.05,0.01$, or 0.001 , respectively. 
Table 3. Contrasts within time from the univariate analysis of variance with repeated time measurements. Data are presented in Fig. 1.

\begin{tabular}{lccc}
\hline \hline & $0 \mathrm{vs}$. & $30 \mathrm{vs}$. & $0 \mathrm{vs}$. \\
& $30 \mathrm{~min}$ & $180 \mathrm{~min}$ & $180 \mathrm{~min}$ \\
\hline Medium & $* * *$ & $* * *$ & Ns \\
Irrigation method & $* * *$ & $* * *$ & $* * *$ \\
\hline $\begin{array}{l}\text { Ns, }{ }^{* * *} \text { Nonsignificant } \\
\text { respectively. }\end{array}$
\end{tabular}

media. Medium $\mathrm{O}_{2}$ PP in the top and middle layers after the irrigation were similar to the pre-irrigation $\mathrm{O}_{2}$ level.

The elevated $\mathrm{CO}_{2} \mathrm{PP}$ in the root media with drip irrigation were not expected, and the $\mathrm{CO}_{2}$ source was not immediately clear. The possibility that the $\mathrm{CO}_{2}$ evolved from either root respiration or microbial activity in the medium was considered first, given the differences in organic-matter content among the three media. Perhaps as water was absorbed into the root medium, the air-filled porosity and gas diffusion decreased, which caused an increase in the $\mathrm{CO}_{2}$ PP. A second possibility was that the bicarbonate in the irrigation water was neutralized by the acidic peat to release $\mathrm{CO}_{2}$. The increase in medium $\mathrm{CO}_{2}$ also may have been due to unreacted or residual lime contained in the root medium, which solubilized and reacted with the acidic peat during the irrigation, resulting in the increased $\mathrm{CO}_{2}$ production.

When RO purified water was applied to $100 \%$ peat and $50 \%$ peat and $50 \%$ vermiculite media, there was no marked increase in $\mathrm{CO}_{2}$ in the top or middle layers (Fig. 2). Compared to pre-irrigation medium $\mathrm{CO}_{2}$ levels, there was an increase in the $\mathrm{CO}_{2}$ PP $10 \mathrm{~min}$ after the irrigation with $\mathrm{RO}$ water $(70 \mathrm{~Pa})$, indicating that plant or medium respiration or the reaction of residual lime may have a slight effect on medium $\mathrm{CO}_{2} \mathrm{PP}$ during and after the irrigation. In comparison, applying well water containing $\mathrm{CaCO}_{3}$ alkalinity at $320 \mathrm{mg} \cdot \mathrm{liter}^{-1}$ caused an increase in medium $\mathrm{CO}_{2}(\leq 1010 \mathrm{~Pa})$ 10 min after the irrigation, indicating that the primary source of the increase in $\mathrm{CO}_{2}$ (Fig. 1) was from the alkalinity in the well water.

Water absorption with subirrigation is fundamentally different from that with topwatering methods, such as drip irrigation. With subirrigation, water saturates the bottom layers first and then moves to the higher layers by capillary action. In the top and middle layer, the air-filled porosity should not have been less than that measured at container capacity. With drip irrigation, not only was more highbicarbonate water applied to the root medium than with subirrigation (because water was leached), but the water flowed through the pore spaces of the top and middle layers. Until drainage stopped, the air-filled porosity of the top and middle layers would have been less than that measured at container capacity. The lower air-filled porosity during and after the drip irrigation could have, in part, caused the larger increase in the medium $\mathrm{CO}_{2} \mathrm{PP}$ compared to that measured with subirrigation.

There were differences in the $\mathrm{pH}$ of the root medium layer that came into contact with the applied irrigation water. The root medium $\mathrm{pH}$ of the top layer of the drip-irrigated pots ranged from 5.8 to 7.3 (Table 4). In comparison, the root medium $\mathrm{pH}$ of the bottom layer of subirrigated pots ranged from 6.8 to 8.0. It cannot be determined from this experiment if the increase in medium $\mathrm{CO}_{2}$ would have been similar under both irrigation methods if the root medium $\mathrm{pH}$ had been similar.

The high $\mathrm{CO}_{2}$ levels quickly declined and, by $180 \mathrm{~min}$ after the irrigation, had decreased from an average of 820 to $90 \mathrm{~Pa}$ (Fig. 1, Table $3)$. Differences in medium $\mathrm{CO}_{2} \mathrm{PP}$ still remained between the two irrigation methods $($ drip irrigated $=110 \mathrm{~Pa}$, subirrigated $=90 \mathrm{~Pa})$ compared to that measured before the irrigation. However, the differences were small when compared to those measured between 30 and $180 \mathrm{~min}$ after the irrigation. Medium $\mathrm{O}_{2} \mathrm{PP}$ increased to pre-irrigation lev- els $(21 \mathrm{kPa})$ in media given drip irrigation.

In general, soilless container root media maintain high air-filled porosities in pots (DeBoodt and Verdonck, 1971; Fonteno, 1988; Milks et al., 1989). At container capacity, the average air space in the three root media tested was between $21 \%$ and $32 \%$ of the total volume in a $15-\mathrm{cm}$-tall pot (Table 1). This high porosity after the irrigation allowed rapid $\mathrm{CO}_{2}$ dispersion and re-establishment of $\mathrm{O}_{2} \mathrm{PP}$ to near pre-irrigation levels.

The bicarbonate alkalinity in the irrigation water, not root or microbial respiration, was the primary source of medium $\mathrm{CO}_{2}$ in this experiment. Only limited conclusions about the effect of irrigation method on medium $\mathrm{CO}_{2}$ PP can be made because of the water alkalinity effect and differences in the root medium $\mathrm{pH}$ between irrigation treatments. Further study is

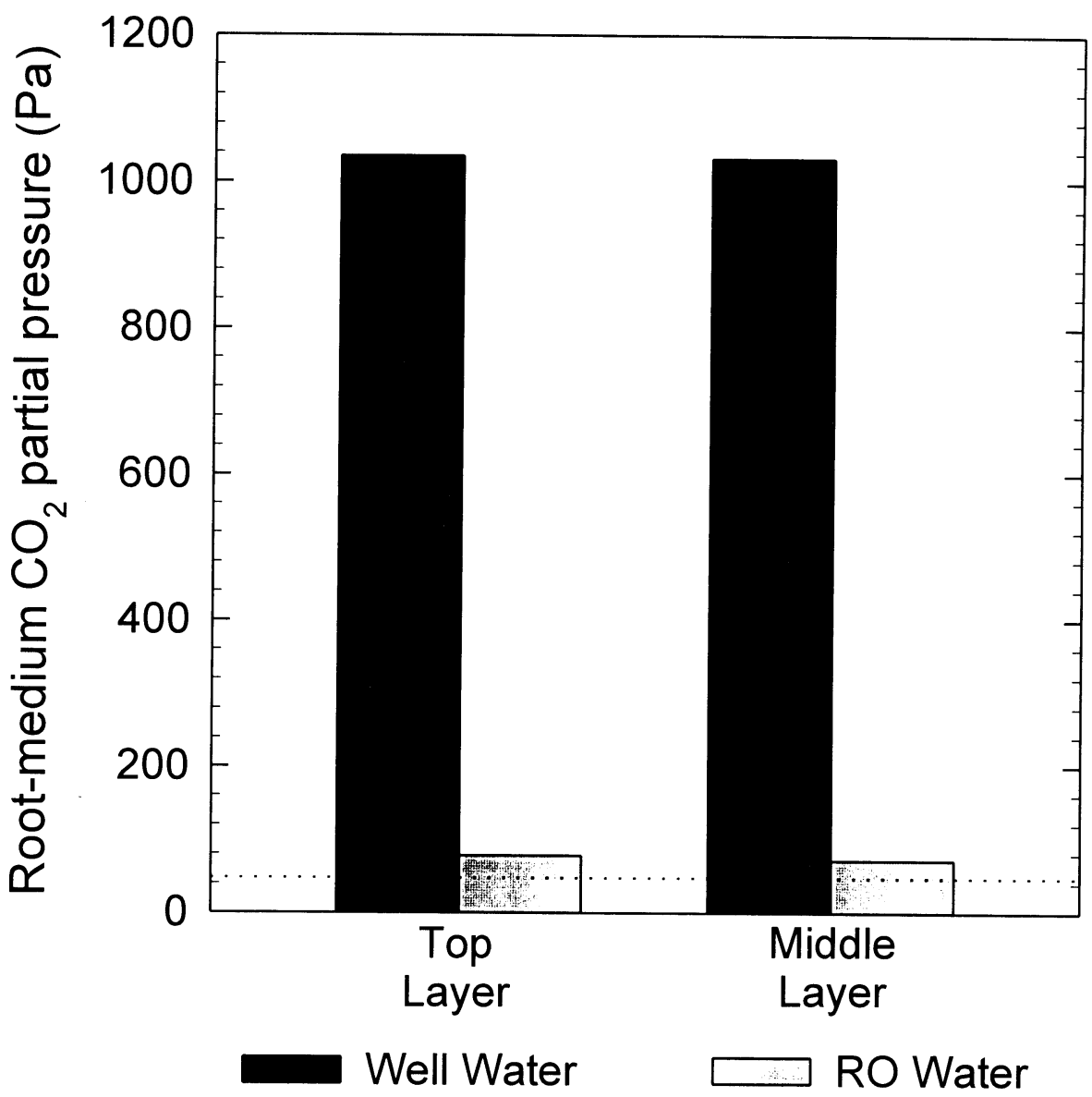

Fig. 2. Top- and middle-layer $\mathrm{CO}_{2}$ partial pressure of drip-irrigated, 15 -cm-tall $\times 15$-cm-wide pots containing flowering chrysanthemums using well water or reverse-osmosis distilled water. Gas samples were taken $10 \mathrm{~min}$ after the irrigation. Dotted line indicates the ambient $\mathrm{CO}_{2}$ partial pressure inside the greenhouse. Data represent the mean of two pots containing either $100 \%$ peat or $50 \%$ peat and $50 \%$ vermiculite medium.

Table 4. Root medium $\mathrm{pH}$ of chrysanthemums grown in three root media using drip irrigation or subirrigation at three levels within the same pot. Root medium was sampled 1 week after the gas samples were taken. Data are means of six pots. Least significant difference (5\%) calculated using pooled SE of the data presented for root medium $\mathrm{pH}=0.4$.

\begin{tabular}{|c|c|c|c|c|c|c|}
\hline \multirow[b]{3}{*}{ Medium } & \multicolumn{6}{|c|}{ Medium $\mathrm{pH}$} \\
\hline & \multicolumn{3}{|c|}{ Drip irrigation } & \multicolumn{3}{|c|}{ Subirrigarion } \\
\hline & Top & Middle & Bottom & Top & Middle & Bottom \\
\hline $100 \%$ peat & 6.3 & 6.0 & 5.9 & 5.8 & 6.1 & 6.7 \\
\hline $50 \%$ peat and $50 \%$ vermiculite & 6.3 & 6.0 & 5.9 & 6.0 & 6.1 & 6.9 \\
\hline $100 \%$ vermiculite & 7.0 & 6.8 & 6.8 & 7.1 & 8.1 & 8.0 \\
\hline
\end{tabular}


needed to quantify the effects of irrigation method on media $\mathrm{CO}_{2} \mathrm{PP}$ in container root media over the duration of a crop, not just at flowering, and to determine if the increase in medium $\mathrm{CO}_{2}$ PP has any negative effect on plant growth. Future experiments should beperformed with consideration for the effects of water alkalinity, perhaps using $\mathrm{CaCO}_{3}$-free water to minimize its effect on medium $\mathrm{CO}_{2} \mathrm{PP}$.

\section{Literature Cited}

Bunt, A.C. 1988. Media and mixes for containergrown plants. 2nd ed. Unwin Hyman, London.

Chau, A.S.Y. 1984. Water; and salt, p. 617-638. In: S. Williams (ed.). Official methods of analysis of the association of official analytical chemists. Assn. Offic. Anal. Chemists, Arlington, Va.

DeBoodt, M. and O. Verdonck. 1971. Physical properties of peat and peat-moulds improved by perlite and foam-plastics in relation to ornamental plant-growth. Acta Hort. 18:9-27.

Fonteno, W.C. 1988. Know your media, the air, water, and container connection. GrowerTalks 51:110-111.

Greenhouse, S.W. and S. Geisser. 1959. On methods in the analysis of profile data. Psychometricka 32:95-112.

Hanan, J.J. 1964. Oxygen and carbon dioxide concentrations in greenhouse soil-air. Proc. Amer. Soc. Hort. Sci. 84:648-652.

Lindsay, W.L. 1979. Chemical equilibria in soils. Wiley, New York.
Milks, R.R., W.C. Fonteno, and R.A. Larson. 1989. Hydrology of horticultural substrates: II. Predicting physical properties of media in containers. J. Amer. Soc. Hort. Sci. 114:53-56.

Muckle, E. 1990. Oxygen, internal combustion fuel of plant growth. 21st Century Grower 4:26-28.

Ott, L. 1988. An introduction to statistical methods and data analysis. PWS-Kent Publishing, Boston.

Paul, J.L. and C.I. Lee. 1976. Relation between growth of chrysanthemums and aeration of various container media. J. Amer. Soc. Hort. Sci. 101:500-503.

White, J.W. and J.W. Mastalerz. 1966. Soil moisture as related to container capacity. Proc. Amer. Soc. Hort. Sci. 89:758-765. 